\title{
Helical Arrangement of 2-(4-hydroxy-3-methoxyphenyl)-Benzothiazole in Crystal Formation and Biological Evaluation on HeLa Cells
}

\author{
Roberto I. Cuevas-Hernández ${ }^{1}$, Itzia I. Padilla-Martínez ${ }^{2}$, Sarai Martínez-Cerón ${ }^{1}$, \\ Ismael Vásquez-Moctezuma ${ }^{1}$ and José G. Trujillo-Ferrara ${ }^{1, *}$ \\ 1 Laboratorio de Investigación en Bioquímica, Escuela Superior de Medicina, Instituto Politécnico Nacional, \\ Plan de San Luis y Díaz Mirón s/n Casco de Santo Tomás, Mexico City 11340, Mexico; \\ rcuevash@ipn.mx (R.I.C.-H.); sara_smc89@hotmail.com (S.M.-C.); g17isma65@gmail.com (I.V.-M.) \\ 2 Laboratorio de Química Supramolecular y Nanociencias, Instituto Politécnico Nacional-UPIBI, \\ Av. Acueducto s/n Barrio la Laguna Ticomán, Ciudad de México C.P. 07340, Mexico; ipadillamar@ipn.mx \\ * Correspondence: jtrujillo@ipn.mx; Tel.: +52-55-5729-6000 (ext. 62747)
}

Academic Editor: Sławomir J. Grabowski

Received: 3 May 2017; Accepted: 7 June 2017; Published: 11 June 2017

\begin{abstract}
Benzothiazoles are a set of molecules with a broad spectrum of biological applications. In particular, 2-(4-hydroxy-3-methoxyphenyl)-benzothiazole is a potential breast cancer cell suppressor whose mechanism of action has been previously reported. In the present work, the title compound was synthesized, crystallized, and its biological activity on HeLa cells was evaluated. Its molecular structure was compared to that obtained by molecular modeling. Theoretical calculations suggest that the syn-rotamer is the most stable form and correlates very well with crystallographic data. The crystal structure adopts a helical arrangement formed through $\mathrm{O} 13-\mathrm{H} 13 \cdots \mathrm{N} 3$ intermolecular hydrogen bonding that propagates in the (14-1 -3) plane. These results suggest that the title compound has the capacity to interleave into DNA and better explain its biological effects related to the increased CHIP expression through AhR recruitment. Finally, the biological experiments indicate that the title compound has the capacity to decrease the viability of HeLa cells with an $\mathrm{IC}_{50}=2.86 \mu \mathrm{M}$.
\end{abstract}

Keywords: helical arrangement of benzothiazole; rotational energy properties; HeLa cells

\section{Introduction}

Benzothiazoles are a class of bicyclic compounds with a broad spectrum of biological applications such as neuroprotective effects [1,2], antimicrobial activity [3-6], antioxidant and radioprotective effects [7], anticonvulsant activity [8,9] and antitumor properties [10,11]. In particular, 2-(4-hydroxy-3-methoxyphenyl)-benzothiazole has been reported to be a tyrosinase inhibitor against hyperpigmentation [12]. Recent studies showed that this compound and its analogues promote signaling and nuclear translocation of Aryl hydrocarbon Receptor (AhR) and induce the carboxyl terminus of Hsp70-interacting protein (CHIP) expression through recruitment of AhR upstream of the CHIP gene. This mechanism has potential application in the suppression of tumor progression in breast cancer cells [13-17]. The synthesis of the title compound has been recently improved by using several catalysts such as $\mathrm{LiBr}$ [18], ZnO [19] and CdS [20], silica [21], nanoparticles, clays [22,23], and transition metals $[24,25]$. The number of synthetic methods reflects the importance of this compound. In this paper, 2-(4-hydroxy-3-methoxyphenyl)-benzothiazole was synthetized, crystalized, and its molecular X-ray structure was compared with that simulated by theoretical calculations. Furthermore, its activity on cervical cancer cell line (HeLa) was evaluated. 


\section{Results and Discussion}

\subsection{Molecular Structure}

The title compound crystallizes in an orthorhombic system, space group $\mathrm{P} 2{ }_{1} 2_{1} 2{ }_{1}$, with four molecules in the unit cell. Its X-ray molecular structure is depicted in Figure 1. The bond distances

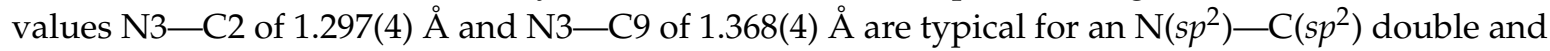
single bond order character, respectively, whereas $\mathrm{C} 2-\mathrm{C} 10$ bond distance of $1.453(4)$ has a value for a typical single $\mathrm{Cs} p^{2}-\mathrm{Cs} p^{2}$ bond [26]. Bond lengths values S1-C2 of 1.735(3) A and S1—C8 of 1.724(3) $\AA$ are characteristic for a single $\mathrm{S}-\mathrm{Csp} \mathrm{p}^{2}$ bond. Phenol and methyl ether $\mathrm{C}-\mathrm{O}$ distances $\mathrm{O} 13-\mathrm{C} 13$ of 1.337(4) $\AA$ and O14 - C14 of 1.358(4) $\AA$, respectively, are significantly smaller than the usual values (Car-O of 1.362(15) in phenols and 1.370(11) in ethers), but similar to the value found in the structure of 2-(4-hydroxyphenyl)benzothiazole [27]. Both phenyl (Ph) (C10-C15) and benzothiazole (BZT) (S1/C2/N3/C4-C9) rings are planar. The atoms C12 in the former and C2 in the latter deviate 0.004(4) $\AA$ and 0.006(3) $\AA$, respectively, from their corresponding mean planes. The Ph ring is almost coplanar with the benzothiazole moiety; the torsion angle between the two rings is $4.69(7)^{\circ}$, which is more coplanar than the same angle in 2-(4-hydroxyphenyl)benzothiazole $\left(18.49(6)^{\circ}\right)$. Phenol and methyl ether moieties are coplanar with a $\mathrm{O} 13-\mathrm{C} 13-\mathrm{C} 14-\mathrm{O} 14$ torsion angle value of $-1.0(5)^{\circ}$.

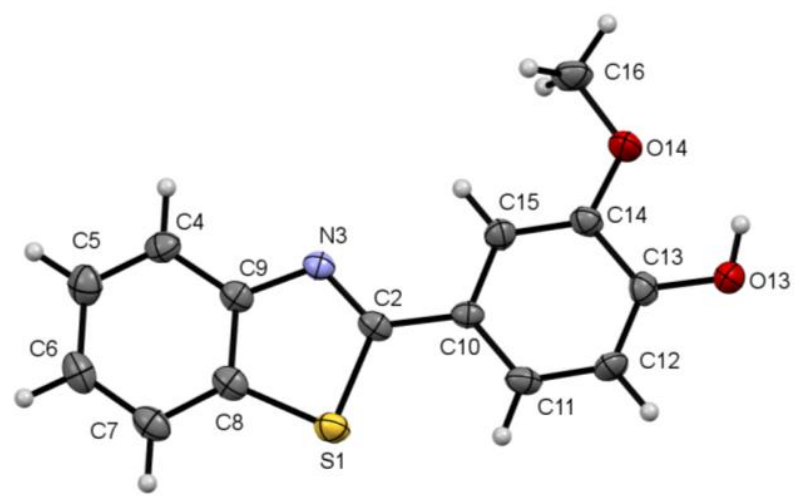

Figure 1. X-ray crystal structure of 4-(1,3-benzothiazol-2-yl)-2-methoxyphenol with atom labeling scheme. Ortep view at $30 \%$ probability level.

\subsection{Theoretical Molecular Modeling}

The DFT theoretical calculations showed that the optimized structure is similar to the X-ray experimental structure. The geometric parameters of both the experimental and theoretical calculations are listed in Table 1. The rotational barrier around the $\mathrm{C} 2-\mathrm{C} 10$ bond was calculated in order to establish the structure of the most stable rotamer. Starting from the rotamer with the OMe group on the same side as the heterocyclic nitrogen (syn), the value of the rotational barrier is $7.12 \mathrm{kcal} / \mathrm{mol}$. However, syn- and anti-rotamers are almost of the same energy with a difference of only $1.51 \mathrm{kcal} / \mathrm{mol}$ in favor of the syn structure. The title compound crystallizes in the most stable form, the syn-rotamer, whose calculated dipolar moment is smaller (2.6331 D) than the calculated value for the anti form (3.3379 D), as shown in Figure 2. 
Table 1. Comparison between modeled and crystal geometric structures of 2-(4-hydroxy-3methoxyphenyl)-benzothiazole.

\begin{tabular}{|c|c|c|}
\hline & Modeled Structure & Crystal Structure \\
\hline Energy $(\mathrm{kcal} / \mathrm{mol})$ & -717529.76 & \\
\hline$E_{\mathrm{HOMO}}(\mathrm{kcal} / \mathrm{mol})$ & -136.91 & \\
\hline$E_{\text {LUMO }}(k c a l / m o l)$ & -41.60 & \\
\hline GAP $(k c a l / m o l)$ & -178.52 & \\
\hline \multicolumn{3}{|l|}{ Bond lengths (Å) } \\
\hline N3-C9 & 1.398 & $1.368(4)$ \\
\hline $\mathrm{N} 3-\mathrm{C} 2$ & 1.299 & $1.297(4)$ \\
\hline $\mathrm{C} 2-\mathrm{S} 1$ & 1.877 & $1.735(3)$ \\
\hline $\mathrm{S} 1-\mathrm{C} 8$ & 1.815 & $1.724(3)$ \\
\hline $\mathrm{C} 2-\mathrm{C} 10$ & 1.456 & $1.453(4)$ \\
\hline $\mathrm{C} 13-\mathrm{C} 14$ & 1.409 & $1.400(5)$ \\
\hline $\mathrm{O} 13-\mathrm{C} 13$ & 1.381 & $1.337(4)$ \\
\hline $\mathrm{O} 14-\mathrm{C} 14$ & 1.399 & $1.358(4)$ \\
\hline \multicolumn{3}{|l|}{ Bond angles $\left({ }^{\circ}\right)$} \\
\hline $\mathrm{N} 3-\mathrm{C} 2-\mathrm{S} 1$ & 113.5 & $115.0(2)$ \\
\hline $\mathrm{C} 2-\mathrm{C} 10-\mathrm{C} 11$ & 122.7 & $122.1(3)$ \\
\hline $\mathrm{C} 2-\mathrm{C} 10-\mathrm{C} 15$ & 118.1 & 118.7(3) \\
\hline $\mathrm{H}-\mathrm{O} 13-\mathrm{C} 13$ & 109.4 & 109 \\
\hline $\mathrm{C} 16-\mathrm{O} 14-\mathrm{C} 14$ & 118.9 & $118.2(3)$ \\
\hline \multicolumn{3}{|l|}{ Torsion angles $\left({ }^{\circ}\right)$} \\
\hline $\mathrm{N} 3-\mathrm{C} 2-\mathrm{C} 10-\mathrm{C} 11$ & -179.987 & $174.7(3)$ \\
\hline $\mathrm{N} 3-\mathrm{C} 2-\mathrm{C} 10-\mathrm{C} 15$ & 0.012 & $-5.0(5)$ \\
\hline $\mathrm{C} 16-\mathrm{O} 14-\mathrm{C} 14-\mathrm{C} 13$ & -179.995 & $-179.2(3)$ \\
\hline $\mathrm{S} 1-\mathrm{C} 2-\mathrm{C} 10-\mathrm{C} 15$ & -179.985 & $176.2(2)$ \\
\hline $\mathrm{S} 1-\mathrm{C} 2-\mathrm{C} 10-\mathrm{C} 11$ & 0.016 & $-4.1(4)$ \\
\hline $\mathrm{O} 13-\mathrm{C} 13-\mathrm{C} 14-\mathrm{O} 14$ & 0.001 & $-1.0(5)$ \\
\hline
\end{tabular}

A

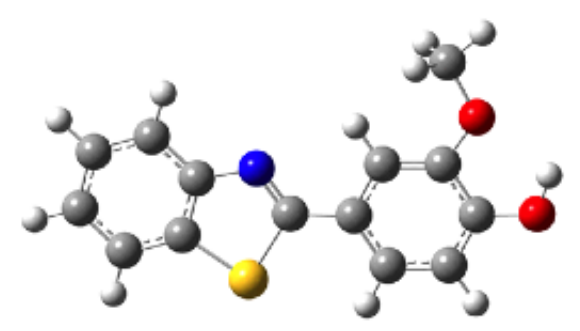

C

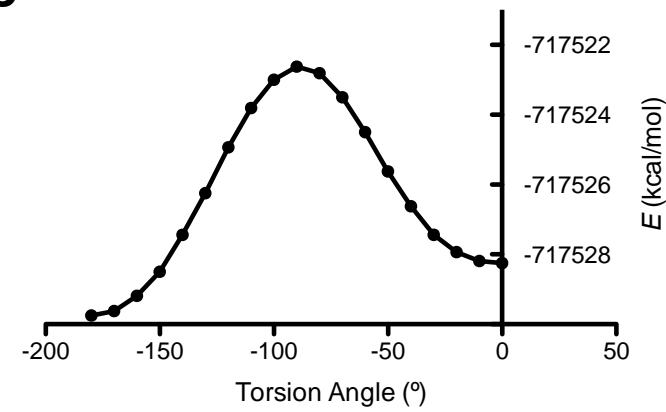

B

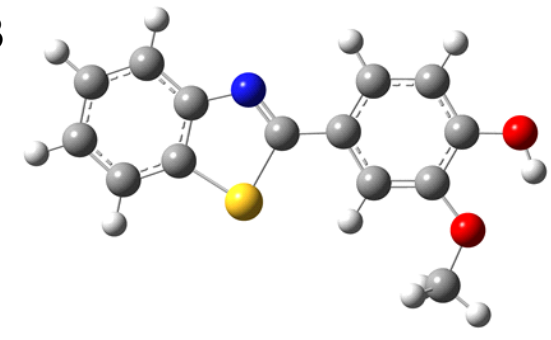

D

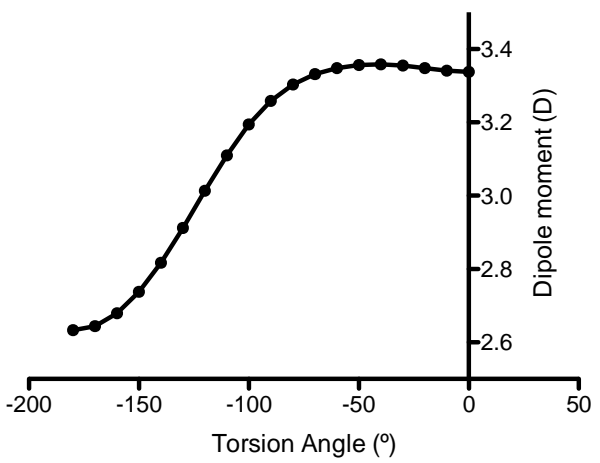

Figure 2. Theoretical calculations for 4-(1,3-benzothiazol-2-yl)-2-methoxyphenol. Molecular structure of: (A) syn-rotamer and (B) anti-rotamer; (C) rotational barrier plot and (D) dipolar moment plot, both depending on the torsion angle of $\mathrm{N} 3-\mathrm{C} 2-\mathrm{C} 10-\mathrm{C} 11$. 


\subsection{Supramolecular Structure}

The hydrogen bonding scheme contributes to the full planarity of the title compound. The graph set notation is used to describe the hydrogen bonding motifs [28]. The phenol hydrogen atom is properly positioned to form an intramolecular hydrogen bond motif, $S(5)$, with the methoxy oxygen

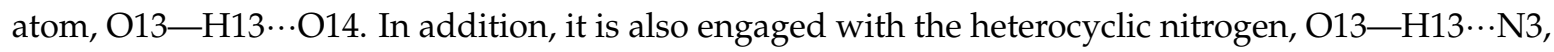
forming a three-centered hydrogen bond, $\mathrm{O} 14 \cdots \mathrm{H} 13 \cdots \mathrm{N} 3$, as the sum of angles around $\mathrm{H} 13$ is $360^{\circ}$ [29]. The phenol oxygen atom also acts as the acceptor of one aryl hydrogen, C15- H15 ․ O13, that assembles the seven-membered ring motif $R^{2}{ }_{2}(7)$, Figure 3A. The propagation of O13-H13 $\cdots \mathrm{N} 3$ in the (14 -1 -3) plane gives rise to the first dimension (1D) in the form of a helix, Figure 3B. The second dimension is developed by weak interactions $\mathrm{C} 16-\mathrm{H} 16 \mathrm{~A} \cdots \mathrm{Ph}$ between the helixes, through the participation of a methyl hydrogen from the methoxy group, as the donor, and the centroid of the hydroxymethoxyphenyl ring, as the acceptor. Details of the geometry of the hydrogen bonding are listed in Table 2.

A

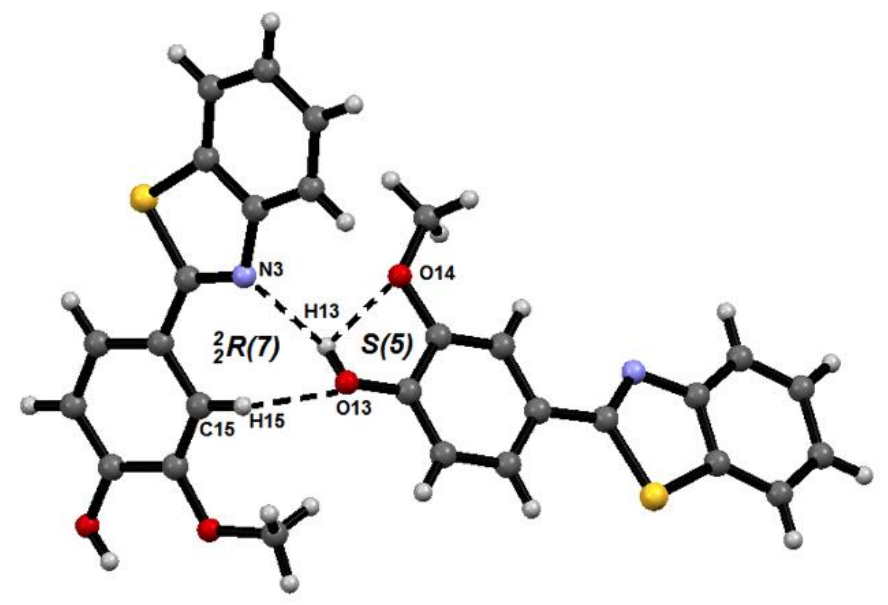

B

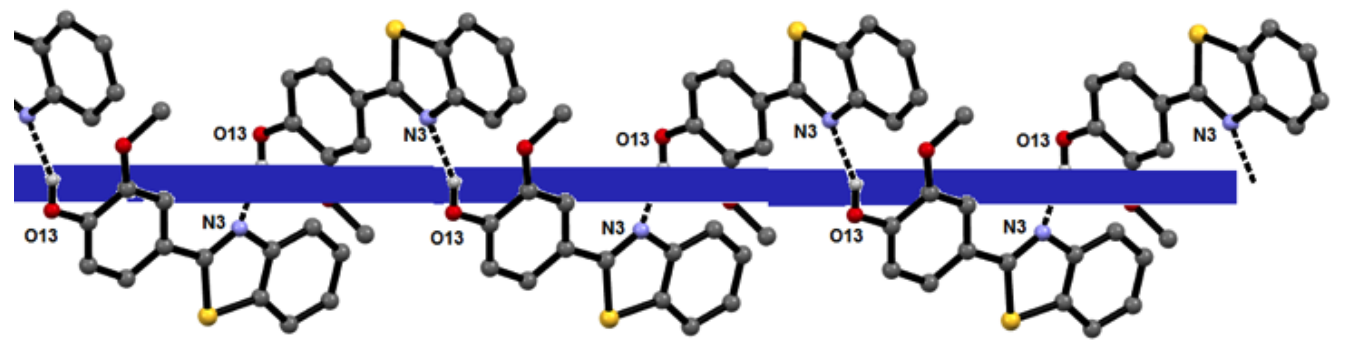

Figure 3. Geometry and three-dimensional arrangement of 2-(4-hydroxy-3-methoxyphenyl)-benzothiazole. (A) Intra and intermolecular hydrogen bonding scheme of the title compound. Intramolecular S(5) and intermolecular $R^{2}{ }_{2}(7)$ motifs are observed; (B) helix formed by through O13-H13 $\cdots \mathrm{N} 3$ hydrogen bonding in the (14 - 1 -3) plane.

Table 2. Hydrogen bonding geometric features of 2-(4-hydroxy-3-methoxyphenyl)-benzothiazole.

\begin{tabular}{ccccc}
\hline $\mathbf{D}-\mathbf{H} \cdots \mathbf{A}$ & $\mathbf{D}-\mathbf{H}(\mathbf{A})$ & $\mathbf{H} \cdots \mathbf{A}(\AA)$ & $\mathbf{D} \cdots \mathbf{A}(\AA)$ & $\mathbf{D}-\mathbf{H} \cdots \mathbf{A}\left({ }^{\circ}\right)$ \\
\hline $\mathrm{O} 13-\mathrm{H} 13 \cdots \mathrm{O} 14$ & 0.84 & 2.24 & $2.669(4)$ & 112 \\
$\mathrm{O} 13-\mathrm{H} 13 \cdots \mathrm{N} 3^{\mathrm{i}}$ & 0.84 & 2.05 & $2.844(4)$ & 157 \\
$\mathrm{C} 15-\mathrm{H} 15 \cdots \mathrm{O} 13^{\text {ii }}$ & 0.95 & 2.40 & $3.339(4)$ & 169 \\
$\mathrm{C} 16-\mathrm{H} 16 \mathrm{~A} \cdots \mathrm{Ph}^{\text {iii }}$ & 0.95 & 2.77 & $3.571(4)$ & 140 \\
\hline
\end{tabular}

Symmetry codes: (i) $1-x, 1 / 2+y, 3 / 2-z$; (ii) $1-x,-1 / 2+y, 3 / 2-z$; (iii) $1+x, y, z$. 


\subsection{In Vitro Citotoxicity Assay on HeLa Cells}

The in vitro assay was performed in order to know the effect of the title compound on a great interest cell line such as the HeLa line. This cell line is derived from cervical cancer and is well established to explore of the effects of the novel drugs such as the title compound on cancer cells. Our results showed a clear effect on the HeLa cells by MTT assay with $\mathrm{IC}_{50}=2.86 \mu \mathrm{M}$, determined after $48 \mathrm{~h}$ of exposure, Figure 4 . This value is consistent with the activity found against MDA-MB-231 cell line, a highly aggressive breast cancer cell line $\left(\mathrm{IC}_{50}=4.02 \mu \mathrm{M}\right.$, determined in an assay after $96 \mathrm{~h}$ of exposure) [17]. These results show a similar behavior to other cell lines because we did not observe a total death of the cells, despite increasing the concentration of the compound. However, the potency of the compound was higher in HeLa cells than in MDA-MB-231 cells, because our assay lasted half the time that was reported for breast cancer cells. Likewise, our results are consistent with the antitumor effect for other benzothiazole-containing compounds such as fluorinated 2-phenylbenzothiazole derivatives with $\mathrm{IC}_{50}$ values between 50 to $0.0001 \mu \mathrm{M}$ [10], as well as 2-(4-Amino-3-methylphenyl) benzothiazole derivatives showed $\mathrm{IC}_{50}$ values between $100 \mathrm{nM}$ to $100 \mu \mathrm{M}[13,14]$. According to these data, the relative potency of this type of compound depends on the origin of the cancer cell line. For this reason, we suggest exploring the activity and mechanism action of benzothiazole-containing compounds in greater detail on HeLa cells and other cancer cell lines.

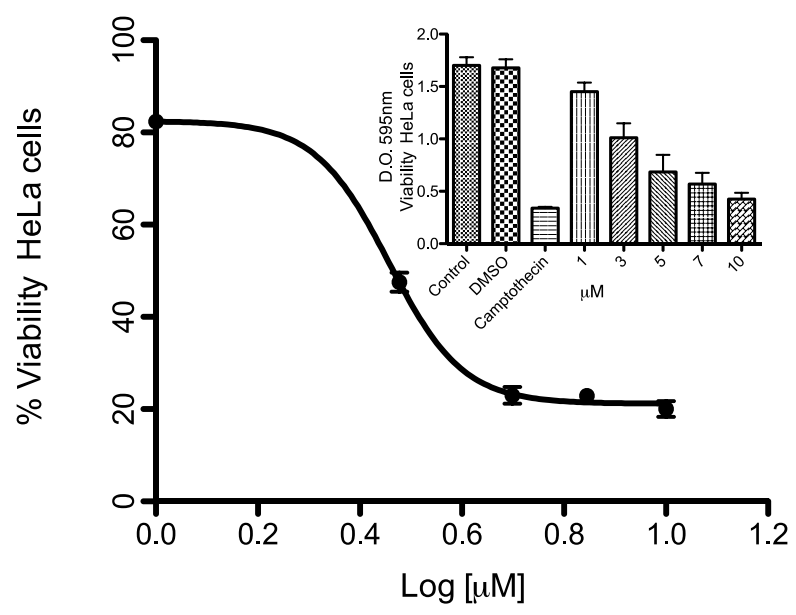

Figure 4. Cytotoxicity of 2-(4-hydroxy-3-methoxyphenyl)-benzothiazole on HeLa cell line. After $48 \mathrm{~h}$ of exposure, an MTT assay was performed and $\mathrm{IC}_{50}=2.86 \mu \mathrm{M}$ was calculated. Camptothecin $1 \mu \mathrm{M}$ was used as a positive control.

\section{Materials and Methods}

\subsection{Instrumental}

The uncorrected melting point was measured in open-ended capillary tubes in an Electrothermal 9300 digital apparatus. ${ }^{1} \mathrm{H}(300.01 \mathrm{MHz})$ and ${ }^{13} \mathrm{C}$ NMR $(75.46 \mathrm{MHz})$ spectra were recorded on a Varian Mercury-300 spectrometer using DMSO- $d_{6}$ as a solvent and TMS as an internal reference. Chemical shift values $(\delta)$ are in parts per million (ppm) and coupling constants ( $\mathrm{v}$ values) are in Hertz $(\mathrm{Hz})$, ESI-MS were recorded on a Bruker micrOTOF-Q II, infrared spectra (IR) was obtained with an ATR/FTIR PerkinElmer Spectrum v10.04.00 and UV/Vis with a Beckman Coulter spectrometer DU 650.

\subsection{Chemical Synthesis and Crystallization}

The compound 2-(4-hydroxy-3-methoxyphenyl)-benzothiazole was synthesized following a reported procedure with modification [30]. All chemicals and solvents were reagent grade and 
used as received. The reaction mixture consisted of $0.259 \mathrm{~g}(1.98 \mathrm{mmol})$ of 2-aminobenzenethiol, $0.319 \mathrm{~g}$ ( $2.1 \mathrm{mmol}$ ) of 4-hydroxy-3-methoxybenzaldehyde and $0.398 \mathrm{~g}(2.1 \mathrm{mmol}) \mathrm{of} \mathrm{Na}_{2} \mathrm{~S}_{2} \mathrm{O}_{5}$ dissolved in $5 \mathrm{~mL}$ of anhydrous DMSO, and was stirred at $393 \mathrm{~K}$ for $45 \mathrm{~min}$. The reaction progress was monitored by TLC (using ethyl acetate:hexane in 1:1 proportion as eluent). The resulting mixture was cooled to room temperature, cold water was added, and the resulting precipitate was collected by filtration. The product was washed with water and left to dry at RT. The gray powder was dissolved in $\mathrm{CH}_{2} \mathrm{Cl}_{2}$ and washed three times with brine. The product was recrystallized three times in $\mathrm{CH}_{2} \mathrm{Cl}_{2}$ solution to obtain $0.443 \mathrm{~g}$ of colorless block-like crystals suitable for X-ray in $87 \%$ yield, m.p. $=162-163{ }^{\circ} \mathrm{C}$; UV (EtOH) $\lambda_{\max }(\log \varepsilon) 332.6$ (4.41); IR (ATR/FTIR, $\left.\mathrm{cm}^{-1}\right): v$ 3400-3096, 1277, 1255 (Ar-OH); 1604, 1585 (Ar-o-disubst.); $1524(\mathrm{C}=\mathrm{N})$; 1191, $1011\left(\mathrm{Ar}-\mathrm{O}-\mathrm{CH}_{3}\right) ;{ }^{1} \mathrm{H}$ NMR $\delta: 10.0(\mathrm{br}, 1 \mathrm{H}, \mathrm{OH}), 8.03(\mathrm{~d}, 1 \mathrm{H}$, $\left.{ }^{3} \mathrm{~J}=8.8, \mathrm{H}-4\right), 7.96\left(\mathrm{~d}, 1 \mathrm{H},{ }^{3} \mathrm{~J}=7.7, \mathrm{H}-7\right), 7.62\left(\mathrm{~d}, 1 \mathrm{H},{ }^{4} \mathrm{~J}=1.7, \mathrm{H}-15\right), 7.48\left(\mathrm{dd}, 1 \mathrm{H},{ }^{3} \mathrm{~J}=8.2,{ }^{4} \mathrm{~J}=1.7, \mathrm{H}-11\right)$, $7.47\left(\mathrm{dd},{ }^{3} \mathrm{~J}=8.2,7.7,1 \mathrm{H}, \mathrm{H}-6\right), 7.38\left(\mathrm{dd}, 1 \mathrm{H},{ }^{3} \mathrm{~J}=8.2,8.8, \mathrm{H}-5\right), 6.91\left(\mathrm{~d}, 1 \mathrm{H},{ }^{3} \mathrm{~J}=8.2, \mathrm{H}-12\right), 3.87(\mathrm{~s}, 3 \mathrm{H}$, $\left.\mathrm{OCH}_{3}\right) ;{ }^{13} \mathrm{C}$ NMR $\delta: 168.0$ (C-2), 154.1 (C-9), 150.5 (C13), 148.5 (C-14), 134.6 (C-8), 126.9 (C-6), 125.4 (C-5), 124.8 (C-10), 122.7 (C-7), 122.5 (C-4), 121.7 (C-11), 116.2 (C-12), 110.4 (C-15), $56.1\left(\mathrm{CH}_{3}\right) ; \mathrm{m} / \mathrm{z}$ (ESI) $258.05[\mathrm{M}+]$.

\subsection{X-ray Diffraction Methods}

Single-crystal X-ray diffraction data was recorded on a D8 Quest CMOS (Bruker, Karlsruhe, Germany) area detector diffractometer with Mo $\mathrm{K} \alpha$ radiation, $\lambda=0.71073 \AA$. The structure was solved by direct methods using SHELXS97 [31] program of WinGX package [32]. The final refinement was performed by the full-matrix least-squares methods on F2 with SHELXL97 program. H atoms on $\mathrm{C}$ were geometrically positioned and treated as riding atoms, with $\mathrm{C}-\mathrm{H}=0.93-0.98 \AA$, and with $\operatorname{Uiso}(\mathrm{H})=1.2 \mathrm{Ueq}(\mathrm{C})$. The program Mercury was used for visualization, molecular graphics and analysis of crystal structures [33]. The software used to prepare material for publication was PLATON [34]. Crystallographic data has been deposited with the Cambridge Crystallographic Data Centre (CCDC) as supplementary publication CCDC number 1539167. Copies of the data can be obtained free of charge upon application to CCDC, 12 Union Road, Cambridge CB2 1EZ, UK, (Fax: +44-01223-336033 or E-Mail: deposit@ccdc.cam.ac.uk).

Crystal Data for $\mathrm{C}_{14} \mathrm{H}_{11} \mathrm{NO}_{26} \mathrm{~S}(\mathrm{M}=257.30 \mathrm{~g} / \mathrm{mol})$ : orthorhombic, space group P2 $2_{1} 2_{1} 2_{1}$ (No. 19), $\mathrm{a}=5.4526(10) \AA, \mathrm{b}=10.993(3) \AA, \mathrm{c}=19.668(5) \AA, \alpha=\beta=\gamma=90^{\circ}, \mathrm{V}=1178.9(5) \AA^{3}, \mathrm{Z}=4, \mathrm{~T}=100(2) \mathrm{K}$, Dcalc $=1.450 \mathrm{~g} / \mathrm{cm}^{3}, 24929$ reflections measured $\left(2.1^{\circ} \leq 2 \Theta \leq 26.1^{\circ}\right), 2324$ unique (Rint $=0.0733$, Rsigma $=0.0287)$ which were used in all calculations. The final R1 was $0.045(\mathrm{I}>2 \sigma(\mathrm{I}))$ and wR2 was 0.097 (all data), $\mathrm{GooF}=1.072$ and Abs. coefficient $=0.266$.

\subsection{Molecular Modeling}

Gaussian 09 software [35] with B3LYP/6-311G(d,p) basis set was used to structure the optimization and vibrational frequencies calculations. Energy calculations of the rotamers around the $\mathrm{C} 2-\mathrm{C} 10$ bond were performed under same basis set.

\subsection{In Vitro Cytotoxicity Assay on HeLa Cells}

HeLa cells $\left(1 \times 10^{3}\right.$ cells/well $)$ in $100 \mu \mathrm{L}$ of DMEM supplemented with $10 \%$ Fetal Bovine Serum were seeded in 96-well culture plates. After $24 \mathrm{~h}$, the cells were treated with fresh medium containing different concentrations or not (negative control) of the title compound $(1,3,5,7$, and $10 \mu \mathrm{M})$ for the following $48 \mathrm{~h}$; camptothecin $1 \mu \mathrm{M}$ was used as positive control. The plates were analyzed for cell survival using the colorimetric 3-(4,5-dimethylthiazol-2-yl)-2,5-diphenyltetrazolium bromide (MTT) dye reduction assay, as described elsewhere [36]. The cytotoxic effect of each treatment was expressed as the percentage of cell survival relative to the untreated control cells, and the concentration of the compound that inhibited $50 \%$ of HeLa cell proliferation $\left(\mathrm{IC}_{50}\right)$ was determined by fitting the data to a typical sigmoidal dose-response curve. 


\section{Conclusions}

In summary, 2-(4-hydroxy-3-methoxyphenyl)-benzothiazole, a potent inhibitor of the growth and invasiveness of breast cancer cells, was crystallized, modulated, and its cytotoxic effect on HeLa cells line was investigated by an in vitro assay. The title compound model is consistent with the obtained crystalline structure, whose conformation leads to the formation of a helix in the crystal lattice. In accordance with previous reports of this structure and other analogues in relation to its mechanism of anticancer action, it is suggested that the conformation found in its crystalline arrangement can directly interact with DNA and provoke damage and cell cycle arrest in cancer cells, in addition to CHIP expression through the recruitment of AhR, as previously demonstrated. Finally, the in vitro experiments showed that the title compound has a cytotoxic effect on HeLa cell line, therefore we suggest that the biological applications of this type of molecule, such as their anticancer effects and their interaction on nucleic acids, continue to be explored in future studies.

Supplementary Materials: The supplementary materials are available online at http:/ /www.mdpi.com/20734352/7/6/171/s1. The ckeckcif.

Acknowledgments: The authors would like to thank Francisco J. Martínez-Martínez from Universidad de Colima for the access to the X-ray diffractometer.

Author Contributions: The chemical synthesis and spectroscopic analysis were performed by Roberto I. Cuevas-Hernández and Sarai Martínez-Cerón; the NMR experiments and the crystal structure were performed and analyzed by Itzia I. Padilla-Martínez; interpretation of data, collection, and assembly of data were conducted by José G. Trujillo-Ferrara; in vitro experiments on HeLa cells line were carried out by Ismael Vásquez-Moctezuma. The draft of the paper was written by Roberto I. Cuevas-Hernández and Itzia I. Padilla-Martínez. All authors have given approval to the final version of the paper.

Conflicts of Interest: All the authors declare no conflict of interest with the design of the study; in the collection, analyses or interpretation of data; in the writing of the manuscript, or in the decision to publish the results.

\section{References}

1. Benazzouz, A.; Boraud, T.; Dubédat, P.; Boireau, A.; Stutzmann, J.M.; Gross, C. Riluzole prevents MPTP-induced parkinsonism in the rhesus monkey: A pilot study. Eur. J. Pharmacol. 1995, 284, $299-307$. [CrossRef]

2. Bae, H.-J.; Lee, Y.-S.; Kang, D.-W.; Gu, J.-S.; Yoon, B.-W.; Roh, J.-K. Neuroprotective effect of low dose riluzole in gerbil model of transient global ischemia. Neurosci. Lett. 2000, 294, 29-32. [CrossRef]

3. Delmas, F.; Avellaneda, A.; Di Giorgio, C.; Robin, M.; De Clercq, E.; Timon-David, P.; Galy, J.P. Synthesis and antileishmanial activity of (1,3-benzothiazol-2-yl) amino-9-(10H)-acridinone derivatives. Eur. J. Med. Chem. 2004, 39, 685-690. [CrossRef] [PubMed]

4. Sheng, C.; Zhu, J.; Zhang, W.; Zhang, M.; Ji, H.; Song, Y.; Xu, H.; Yao, J.; Miao, Z.; Zhou, Y.; et al. 3D-QSAR and molecular docking studies on benzothiazole derivatives as Candida albicans N-myristoyltransferase inhibitors. Eur. J. Med. Chem. 2007, 42, 477-486. [CrossRef] [PubMed]

5. Soni, B.; Ranawat, M.S.; Sharma, R.; Bhandari, A.; Sharma, S. Synthesis and evaluation of some new benzothiazole derivatives as potential antimicrobial agents. Eur. J. Med. Chem. 2010, 45, 2938-2942. [CrossRef] [PubMed]

6. Sahu, P.K.; Sahu, P.K.; Gupta, S.K.; Thavaselvam, D.; Agarwal, D.D. Synthesis and evaluation of antimicrobial activity of $4 \mathrm{H}$-pyrimido[2,1-b]benzothiazole, pyrazole and benzylidene derivatives of curcumin. Eur. J. Med. Chem. 2012, 54, 366-378. [CrossRef] [PubMed]

7. Cressier, D.; Prouillac, C.; Hernandez, P.; Amourette, C.; Diserbo, M.; Lion, C.; Rima, G. Synthesis, antioxidant properties and radioprotective effects of new benzothiazoles and thiadiazoles. Bioorg. Med. Chem. 2009, 17, 5275-5284. [CrossRef] [PubMed]

8. Kumar, P.; Shrivastava, B.; Pandeya, S.N.; Tripathi, L.; Stables, J.P. Design, synthesis, and anticonvulsant evaluation of some novel 1, 3 benzothiazol-2-yl hydrazones/acetohydrazones. Med. Chem. Res. 2012, 21, 2428-2442. [CrossRef]

9. Navale, A.; Pawar, S.; Deodhar, M.; Kale, A. Synthesis of substituted benzo[d]thiazol-2-ylcarbamates as potential anticonvulsants. Med. Chem. Res. 2013, 22, 4316-4321. [CrossRef] 
10. Mortimer, C.G.; Wells, G.; Crochard, J.P.; Stone, E.L.; Bradshaw, T.D.; Stevens, M.F.; Westwell, A.D. Antitumor benzothiazoles. 26.1 2-(3,4-dimethoxyphenyl)-5- fluorobenzothiazole (GW 610, NSC 721648), a simple fluorinated 2-arylbenzothiazole, shows potent and selective inhibitory activity against lung, colon, and breast cancer cell lines. J. Med. Chem. 2006, 49, 179-185. [CrossRef] [PubMed]

11. Wells, G.; Lowe, P.R.; Stevens, M.F. Antitumor benzothiazoles. 13. (Diacetoxy)iodobenzene (DAIB) oxidation of 2-(4-hydroxy-3- methoxyphenyl)benzothiazole and related compounds in the presence of dienophiles. ARCHIVOC 2000, 779-797. [CrossRef]

12. Ha, Y.M.; Park, J.Y.; Park, Y.J.; Park, D.; Choi, Y.J.; Kim, J.M.; Lee, E.K.; Han, Y.K.; Kim, J.A.; Lee, J.Y.; et al. Synthesis and biological activity of hydroxy substituted phenyl-benzo[d]thiazole analogues for antityrosinase activity in B16 cells. Bioorg. Med. Chem. Lett. 2011, 21, 2445-2449. [CrossRef] [PubMed]

13. Hutchinson, I.; Chua, M.S.; Browne, H.L.; Trapani, V.; Bradshaw, T.D.; Westwell, A.D.; Stevens, M.F. Antitumor benzothiazoles. 14. Synthesis and in vitro biological properties of fluorinated 2-(4-aminophenyl) benzothiazoles. J. Med. Chem. 2001, 44, 1446-1455. [CrossRef] [PubMed]

14. Loaiza-Pérez, A.I.; Trapani, V.; Hose, C.; Singh, S.S.; Trepel, J.B.; Stevens, M.F.; Bradshaw, T.D.; Sausville, E.A. Aryl hydrocarbon receptor mediates sensitivity of MCF-7 breast cancer cells to antitumor agent 2-(4-Amino-3-methylphenyl) benzothiazole. Mol. Pharmacol. 2002, 61, 13-19. [CrossRef] [PubMed]

15. Trapani, V.; Patel, V.; Leong, C.O.; Ciolino, H.P.; Yeh, G.C.; Hose, C.; Trepel, J.B.; Stevens, M.F.; Sausville, E.A.; Loaiza-Pérez, A.I. DNA damage and cell cycle arrest induced by 2-(4-amino-3-methylphenyl)-5fluorobenzothiazole (5F 203, NSC 703786) is attenuated in aryl hydrocarbon receptor deficient MCF-7 cells. Br. J. Cancer 2003, 88, 599-605. [CrossRef] [PubMed]

16. Leong, C.O.; Suggitt, M.; Swaine, D.J.; Bibby, M.C.; Stevens, M.F.; Bradshaw, T.D. In vitro, in vivo, and in silico analyses of the antitumor activity of 2-(4-amino-3-methylphenyl)-5-fluorobenzothiazoles. Mol. Cancer Ther. 2004, 3, 1565-1575. [PubMed]

17. Hiyoshi, H.; Goto, N.; Tsuchiya, M.; Lida, K.; Nakajima, Y.; Hirata, N.; Kanda, Y.; Nawasawa, K.; Yanagisawa, J. 2-(4-Hydroxy-3-methoxyphenyl)-benzothiazole suppresses tumor progression and metastatic potential of breast cancer cells by inducing ubiquitin ligase CHIP. Sci. Rep. 2014, 4. [CrossRef] [PubMed]

18. Gill, C.H.; Nikam, M.D.; Mahajan, P.S.; Chate, A.V.; Dabhade, S.K.; Badadhe, P.V. Lithium bromide catalyzed efficient and convenient synthesis of 2-arylbenzothiazole derivatives. Res. Chem. Intermed. 2015, 41, 7509-7516. [CrossRef]

19. Banerjee, S.; Payra, S.; Saha, A.; Sereda, G. ZnO nanoparticles: A green efficient catalyst for the room temperature synthesis of biologically active 2-aryl-1,3-benzothiazole and 1,3-benzoxazole derivatives. Tetrahedron Lett. 2014, 55, 5515-5520. [CrossRef]

20. Sudipto, D.; Suvendu, S.; Swarup, K.M.; Partha, K.K.S.; Amit, K.D.; Divesh, N.S.; Bibhutosh, A.; Papu, B. Visible-light-driven synthesis of 2-substituted benzothiazoles using CdS nanosphere as heterogenous recyclable catalyst. Tetrahedron Lett. 2013, 54, 1090-1096. [CrossRef]

21. Chen, G.F.; Zhang, L.Y.; Jia, H.M.; Chen, B.H.; Li, J.T.; Wang, S.X.; Bai, G.Y. Eco-friendly synthesis of 2-substituted benzothiazoles catalyzed by silica sulfuric acid. Res. Chem. Intermed. 2013, 39, 2077-2086. [CrossRef]

22. Chen, G.F.; Jia, H.M.; Zhang, L.Y.; Chen, B.H.; Li, J.T. An efficient synthesis of 2-substituted benzothiazoles in the presence of $\mathrm{FeCl} 3$ /Montmorillonite K-10 under ultrasound irradiation. Ultrason. Sonochem. 2013, 20, 627-632. [CrossRef] [PubMed]

23. Chen, G.F.; Xiao, N.; Jing, S.Y.; Li, H.Y.; Chen, B.H.; Han, L.F. A simple and eco-friendly process catalyzed by montmorillonite K-10, with air as oxidant, for synthesis of 2-substituted benzothiazoles. Res. Chem. Intermed. 2015, 41, 5159-5166. [CrossRef]

24. Hyvl, J.; Srogl, J. Copper-Catalyzed Activation of Disulfides as a Key Step in the Synthesis of Benzothiazole Moieties. Eur. J. Org. Chem. 2010, 15, 2849-2851. [CrossRef]

25. Saiwen, L.; Chen, R.; Guo, X.; Yang, H.; Deng, G.; Li, C.H. Iron-catalyzed arylation of benzoazoles with aromatic aldehydes using oxygen as oxidant. Green Chem. 2012, 14, 1577-1580. [CrossRef]

26. Allen, F.H.; Kennard, O.; Watson, D.G.; Brammer, L.; Orpen, A.G.; Taylor, R. Tables of bond lengths determined by X-ray and Neutron Diffraction. Part 1. Bond lengths in Organic compounds. J. Chem. Soc. Perkin Trans. II 1987, S1-S19. [CrossRef]

27. Soon-Beng, T.; Okechuckwu, R.; Siang-Guan, T.; Hoong-Kun, F.; Chinnakali, K. 2-(4-Hydroxyphenyl) benzothiazole. Acta Cryst. 1995, C51, 1629-1630. [CrossRef] 
28. Bernstein, J.; Davis, R.E.; Shimoni, L.; Chang, N.L. Patterns in Hydrogen Bonding: Functionality and Graph Set Analysis in Crystals. Angew. Chem. Int. Ed. Engl. 1995, 34, 1555-1573. [CrossRef]

29. Gómez-Castro, C.Z.; Padilla-Martínez, I.I.; García-Báez, E.V.; Castrejón-Flores, J.L.; Peraza-Campos, A.L.; Martínez-Martínez, F.J. Solid state structure and solution thermodynamics of three-centered hydrogen Bonds $(\mathrm{O} \cdots \mathrm{H} \cdots \mathrm{O})$ using N-(2-benzoyl-phenyl) oxalyl derivatives as model compounds. Molecules 2014, 19, 14446-14460. [CrossRef] [PubMed]

30. Weekes, A.; Bagley, M.C.; Westwell, A.D. An efficient synthetic route to biologically relevant 2phenylbenzothiazoles substituted on the benzothiazole ring. Tetrahedron 2011, 67, 7743-7747. [CrossRef]

31. Sheldrick, G.M. A short history of SHELX. Acta Crystallogr. Sect. A 2008, 64, 112-122. [CrossRef] [PubMed]

32. Farrugia, L.J. WinGX suite for small-molecule single-crystal crystallography. J. Appl. Crystallogr. 1999, 32, 837-838. [CrossRef]

33. Macrae, C.F.; Edgington, P.R.; McCabe, P.; Pidcock, E.; Shields, G.P.; Taylor, R.; Towler, M.; van de Streek, J. Mercury: Visualization and analysis of crystal structures. J. Appl. Crystallogr. 2006, 39, 453-457. [CrossRef]

34. Spek, A.L. Single-crystal structure validation with the program PLATON. J. Appl. Crystallogr. 2003, 36, 7-13. [CrossRef]

35. Frisch, M.J.; Trucks, G.W.; Schlegel, H.B.; Scuseria, G.E.; Robb, M.A.; Cheeseman, J.R.; Scalmani, G.; Barone, V.; Petersson, G.A.; Nakatsuji, H.; et al. Gaussian 09, Revision A.02; Gaussian, Inc.: Wallingford, CT, USA, 2016.

36. Martínez-Ramos, F.; Luna-Palencia, G.R.; Vásquez-Moctezuma, I.; Méndez-Luna, D.; Fragoso-Vázquez, M.J.; Trujillo-Ferrara, J.; Meraz-Ríos, M.A.; Mendieta-Wejebe, J.E.; Correa-Basurto, J. Docking Studies of Glutamine Valproic Acid Derivative (S)-5- amino-2-(heptan-4-ylamino)-5-oxopentanoic Acid (Gln-VPA) on HDAC8 with Biological Evaluation in HeLa Cells. Anticancer Agents Med. Chem. 2016, 16, 1485-1490. [CrossRef] [PubMed]

(C) 2017 by the authors. Licensee MDPI, Basel, Switzerland. This article is an open access article distributed under the terms and conditions of the Creative Commons Attribution (CC BY) license (http:/ / creativecommons.org/licenses/by/4.0/). 